\title{
Physical Activities and Sleeping Habits in Children and Adolescent During Pandemic Covid-19: A Systematic Review
}

\author{
Sarwoko, Titik Anggraeni, Ahmad Syamsul Bahri
}

School of Health Sciences Estu Utomo Boyolali, Central Java, Indonesia

\section{ABSTRACT}

Background:Lockdown during the COVID19 pandemic can affect the behavior of daily habits among children and adolescents. This study aims to determine the effect of the COVID-19 pandemic lockdown on the physical activity and sleeping habits of children and adolescents.

Subjects and Method:This study is a systematic review by searching for articles using the online database PubMed and BASE. The dependent variable is the COVID-19 lockdown. The independent variables are physical activity and sleep habits.

Results:: A total of 8 articles were included in the qualitative analysis. 6 articles explained that the lockdown during the COVID-19 virus pandemic reduced the frequency of physical activity in children and adolescents. 6 articles explained that the lockdown during the COVID19 pandemic caused disturbances in sleep quality and an imbalance of sleep time in children and adolescents.

Conclusion:The lockdown policy or activity restriction during the COVID-19 pandemic significantly reduces physical activity and causes sleep quality disturbances and imbalance sleep time in children and adolescents.

Keywords: COVID-19, children, sleep, physical activities, confinement

\section{Correspondence:}

Sarwoko. Sekolah Tinggi Ilmu Kesehatan Estu Utomo Boyolali. Email: sanuria21@gmail.com. Mobile: 087835594214

\section{Cite this as:}

Sarwoko, Anggraeni T, Bahri AS (2021). Physical Activities and Sleeping Habits in Children and Adolescent During Pandemic Covid-19: A Systematic Review. J Matern Child Health. 06(02): 154-164. https://doi.org/10.26911/thejmch.2021.06.02.03.

cC (i) Journal of Maternal and Child Health is licensed under a Creative Commons cc NC SA Attribution-NonCommercial-ShareAlike 4.0 International License.

\section{BACKGROUND}

The COVID-19 virus pandemic first started in China in December 2019. Then, on March 11, 2020, WHO declared COVID-19 a global pandemic (World Health Organization., 2020). Since then, governments in several countries have started implementing various policies to tackle the spread of virus transmission, one of these policies is the implementation of Lockdown (Xiang et al., 2020). In Indonesia, the change in online or independent learning systems due to the direct discontinuation of the teaching and learning system has resulted in school-age children and adolescents having to stay and carry out their daily activities at home. This may have an impact on children's lifestyles which can change their daily habitual behavior (Guan et al., 2020). The closure of schools resulted in a reduction in school children's activity so that it was possible not to meet the standard time for physical activity recommended by the WHO, namely 60 minutes (Wang et al., 2020). Studies conducted in Italy explain that quarantine or lockdown reduces the amount of physical activity in all age groups, especially in men (Maugeri et al., 2020). This may be due to the prohibition of daily activities that are usually carried out, such as walking to school, doing sports activities in the field or sports clubs, and other outdoor activities (Pombo et al., 2020). Lockdowns may also 
have a significant impact on lifestyle changes that can affect a child's physical and mental health. Research by Sprang and Silman shows that the prevalence of post-traumatic stress disorder (PTSD) is four times more common in children who experience quarantine than those who are not (Sprang et al., 2013). The relationship between sleep disorders and emotional problems such as disorder, depression, stress, and anxiety has long been established, even in children (Baum et al., 2014). Therefore, this study's objectives are 1) to explain the relationship between COVID19 lockdown and physical activity in children and adolescents and 2) to explain the relationship between COVID-19 lockdown and sleep habits in children and adolescents.

\section{SUBJECTS AND METHOD}

\section{Study Design}

The design of this study is a systematic review.

\section{Inclusion Criteria}

Search for articles using the online database PubMed and BASE. The articles used in this review are articles published from 2019 to December 2020. In the process of searching for articles, researchers used the keywords "COVID-19", "children", "sleep", "physical activities", and "confinement". This study's inclusion criteria were: 1) an article that explained the relationship or influence between lockdown and slept habits or physical activity; 2) an original research paper. The exclusion criteria of this study were: 1) articles that use languages other than English and Indonesian; 2) review papers; 3) data is incomplete or unavailable.

\section{Study Variables}

The dependent variable of this study is the lockdown during the COVID-19 virus pandemic. The independent variables of this study were physical activity and sleep habits.

\section{OperationalDefinition of Variables}

Lockdown during the pandemic of the COVID-19 virus is defined as self-quarantine at home or restrictions on the neighborhood's mobilization. Physical activity is defined as the time to do physical activities such as sports and other physical activities. A child's sleep habits are defined as the amount of sleep time and sleep disturbances (sleep anxiety, night wakings, parasomnias, daytime sleepiness, and others) experienced by children and adolescents.

\section{Study Instruments}

Search for articles using an online database. The process of searching and filtering articles uses the Prisma diagram (Figure 1). Articles included in this study must meet the inclusion criteria and have been reviewed using a critical appraisal in accordance with the research design of each article.

\section{RESULTS}

\section{Sample Characteristics}

A total of 8 articles have been submitted to the qualitative synthesis. 6 articles related to the relationship between the COVID-19 lockdown and physical activity in children and adolescents. 6 articles related to the relationship between the COVID-19 lockdown and sleeping habits in children and adolescents. Several articles cover physical activity and sleep habits at the same time. The characteristics of each article have been described in table 2 and table 3 .

\section{The Effect of the COVID-19 Lock- down on the Physical Activities of Children and Adolescents}

The lockdown policy during the COVID-19 virus pandemic had an impact on children and adolescents, one of the impacts was a decrease in the frequency of physical activity. Pombo et al. (2020) explained that there was a reduction in physical activity in children and adolescents during the COVID-19 pandemic lockdown, reduced activity was also influenced by several other factors such as age, having an outdoor area at home, the number of children at home, and parents working from home. According to Medrano et al. (2020) there was a decrease in physical activity for 91 minutes per day and an incre- 
ase in screen time (television and gadgets) by 1.8 hours per day. The study by López-Bueno et al. (2020) also emphasized that there was a reduction in the level of physical activity and an increase in screen time and sleep time during the COVID-19 pandemic lockdown period. Prior to the quarantine or lockdown period, children and adolescents had an average of 30-60 minutes of physical activity per day, but after the quarantine and lockdown period, that number decreased to an average of fewer than 30 minutes per day (Francisco et al., 2020). The study by Arufe-Giráldez et al. (2020) concluded that during the pandemic, the children less than 5 years of age who were the subjects of the study did not meet the standard time of physical activity (180 minutes per day) recommended by WHO. Bonavolontà et al. (2020) explain that children and adolescents who get online support and guidance from teachers or tutors each have better physical activity times than those who do not.

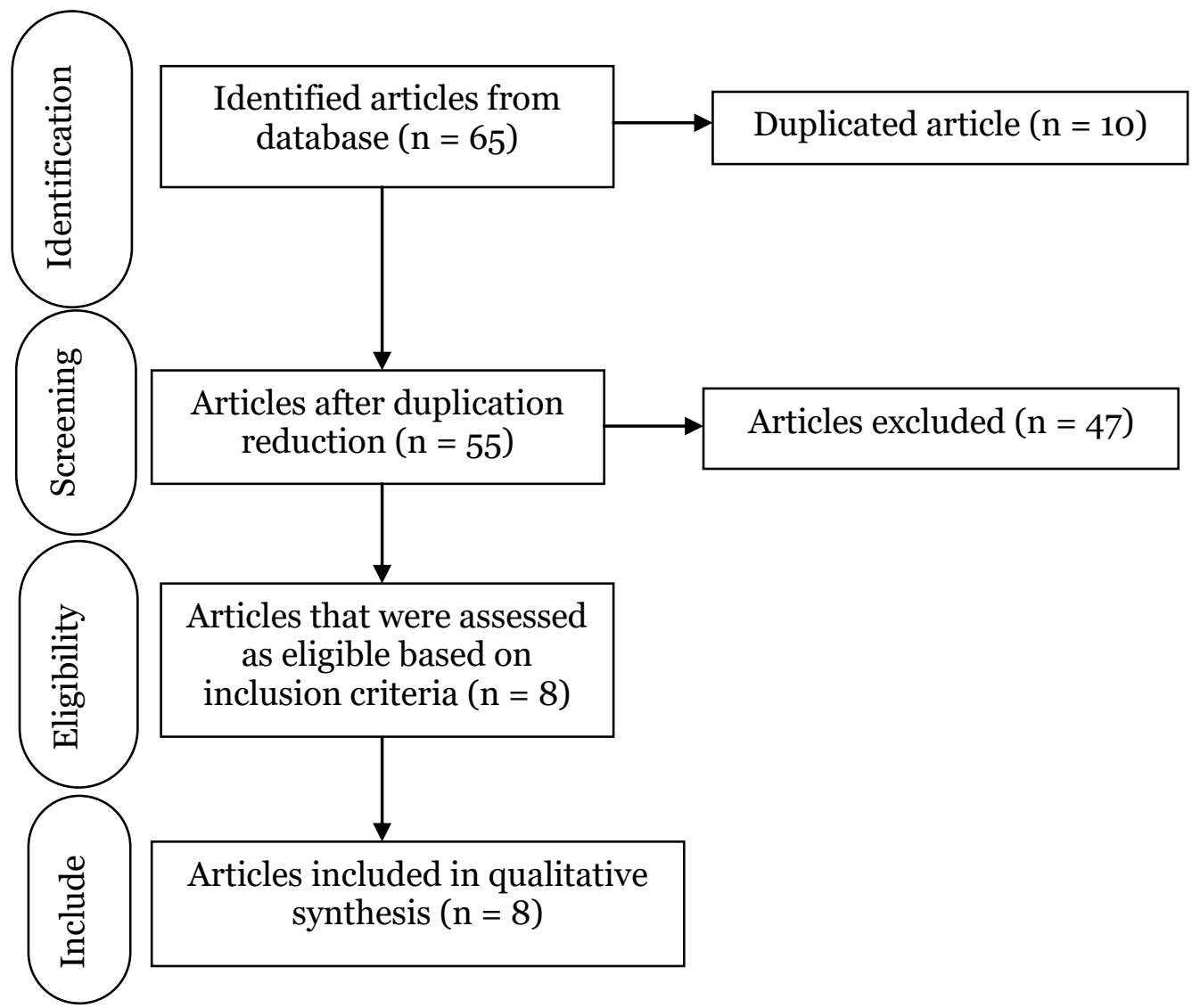

Figure 1. Prisma Diagram

\section{The effect of COVID-19 Lockdown on Sleep Habits in Children and Adolescents}

The study by Medrano et al. (2020) explains that sleep time in children during the lockdown period increases by 0.8 to 1.1 hours/day and on weekends increases by 0.7 to 1.6 hours per day. The study of López-Bueno et al. (2020) shows an increase in sleep time during periods of strict quarantine compared to relaxed and pre-quarantine. Studies in Italy, Portugal, and Spain show that there is a significant increase in sleep time in children during the quarantine or lockdown of the COVID-19 pandemic (Francisco et al., 2020). The study by Arufe-Giráldez et al. (2020) shows that children under 4 years of age who are undergoing quarantine during the COVID-19 pandemic lockdown have met the standard sleep time recommended by WHO 
(10-12 hours/day). Sleep time for children and adolescents during quarantine is delayed by 57 minutes on weekdays and 30 minutes on weekends while waking times are 1 hour 52 minutes longer on weekdays and 1 hour on weekends (Liu et al., 2020) . The study by Cellini et al. (2020) shows that children wake up 1 hour 50 minutes longer during the quarantine period than when they do not, the quarantine policy during the lockdown period also has a significant effect on the quality of children's sleep. Cellini et al. (2020) also explained that sleep quality and sleep time affect children's emotional state, although in the aspect of sleep time, the relationship is not statistically significant.

\section{DISCUSSION}

The review results show that there is a relationship between the lockdown policy during the COVID-19 virus pandemic and the physical activity and sleeping habits of children and adolescents.

\section{Physical Activity of Children and} Adolescents during the Pandemic

The decline in children's physical activity is one of the negative impacts of the quarantine or lockdown policy. The association between social isolation and low physical activity levels has been reported since several decades ago (Andersen et al., 1980). Xiang et al. (2020) reported a decrease in physical activity time of 435 minutes per week during the quarantine period. Pietrobelli et al. (2020) explained that in a sample of 41 obese children in Italy who underwent quarantine for 3 weeks, decreased sports activity (2.30 to 4.60 hours/week) and increased screen time (4.452.40 hours per day). The decrease in physical activity in children and adolescents during the quarantine period of the COVID-19 pandemic may be related to school closures, in which there is no longer any activity going to and from school by walking or cycling (Aires et al., 2011; Aparicio-Ugarriza et al. al., 2020). During the quarantine period, children and adolescents experience a change in habits. There is an increase in screen time (tablets, television, mobile phone, or computer) from less than 1 hour before quarantine to more than 3 hours during quarantine (Francisco et al. , 2020).

\section{Sleep Habits of Children and Adoles- cents during the Pandemic}

Children and adolescents who are undergoing quarantine experience an increase in sleep time, delay in sleep, and delay in waking hours, and some also experience decreased quality of sleep such as waking up in the middle of the night, insomnia, breathing problems during sleep, and sleep disturbances other. According to Paruthi et al. (2016) children and adolescents who experienced quarantine experienced an increase in sleep time of 9.51 hours per night (0.40 hours longer than before quarantine), which is longer than the WHO standard and the American Academy of Sleep Medicine guidelines. However, this increase in sleep time can also result in delays in sleep time and delays in waking hours so that it can result in irregular sleep patterns of children and adolescents (Paavonen et al., 2009). Sleep activity is related to physical and psychological health, especially in young individuals (Becker et al., 2020; Carskadon et al., 2020; Gregory; O'Connor., 2002). One of them is the relationship between sleep duration and behavior and mood problems that affect children's ability to control emotions (Carskadon et al., 2020). The long quarantine period due to the pandemic causes children to delay sleep and wake times, plus an extension of time to do activities such as studying, playing games, and playing social media in bed (Guan et al., 2020). This also affects children's mental health, which can cause psychological disorders, such as depression and anxiety disorders (Widiyanto et al., 2020). Children who have irregular sleep times are more prone to distress and hyperactivity, less frustration tolerance and less focus (Jiao et al., 2020). The risk that causes sleep delay can be caused 
by irregular biological clocks in pre-adolescents children (Carskadon et al., 2020).

This study concludes that the lockdown policy or activity restriction during the $\mathrm{CO}$ VID-19 pandemic significantly reduces physical activity and causes sleep quality disturbances and sleep imbalance in children and adolescents. Parents' attention to children by taking time to do activities together such as gardening and cooking can be an alternative to contribute to the lack of physical activity in children and adolescents. Assistance by parents and efforts to organize children's activities so that they become regular and accustomed to being one of the solution options to overcome this problem. Collaboration with each child's teacher, mentor or tutor may be needed in an effort to synchronize children's activities or activities during the quarantine period at home so that the child has a regular pattern of habits and can have an impact on physical and mental health. This study has not yet discussed the effect of physical activity on children's sleeping habits. This research is also limited to only 2 basic human needs. 
Table 2. Characteristics of Articles on the relationship between COVID-19 Lockdown and Physical Activity in Children who are included in the Qualitative Synthesis

\begin{tabular}{|c|c|c|c|c|c|c|c|}
\hline $\begin{array}{l}\text { Author } \\
\text { (Year) }\end{array}$ & Title & Country & $\begin{array}{l}\text { Study } \\
\text { Design }\end{array}$ & Population & Intervention & Comparison & Outcome \\
\hline $\begin{array}{l}\text { Pombo et al. } \\
(2020)\end{array}$ & $\begin{array}{l}\text { Correlates of } \\
\text { children's physical } \\
\text { activity during the } \\
\text { COVID-19 } \\
\text { confinement in } \\
\text { Portugal. }\end{array}$ & Portugal & $\begin{array}{l}\text { Cross- } \\
\text { sectional }\end{array}$ & $\begin{array}{l}\text { Children } \\
\text { aged } 13 \text { years }\end{array}$ & $\begin{array}{l}\text { During } \\
\text { confinement }\end{array}$ & $\begin{array}{l}\text { Before } \\
\text { confinement }\end{array}$ & $\begin{array}{l}\text { Time allocated for PA } \\
\text { during this period is } \\
\text { reduced compared with } \\
\text { what is usually reported on } \\
\text { normal days }\end{array}$ \\
\hline $\begin{array}{l}\text { Arufe- } \\
\text { Giráldez et } \\
\text { al. (2020) }\end{array}$ & $\begin{array}{l}\text { Sleep, physical } \\
\text { activity and screens } \\
\text { in o-4 years Spanish } \\
\text { children during the } \\
\text { COVID-19 pandemic: } \\
\text { Were the WHO } \\
\text { recommendations } \\
\text { met? }\end{array}$ & Spain & $\begin{array}{l}\text { Descriptive, } \\
\text { comparativ } \\
\text { e, } \\
\text { correlationa } \\
\text { l and cross- } \\
\text { sectional }\end{array}$ & $\begin{array}{l}\text { Children, } \\
\text { aged o-4 } \\
\text { years }\end{array}$ & Confinement & $\begin{array}{l}\text { Standar } \\
\text { recommended } \\
\text { by the WHO }\end{array}$ & $\begin{array}{l}\text { Physical activity levels were } \\
\text { detected to be lower than } \\
\text { recommended, with an } \\
\text { average of } 31.81 \text { minutes } \\
\text { versus the recommended } \\
180 \text { minutes. }\end{array}$ \\
\hline $\begin{array}{l}\text { Medrano et } \\
\text { al. (2020) }\end{array}$ & $\begin{array}{l}\text { Changes in lifestyle } \\
\text { behaviours during the } \\
\text { COVID-19 confine- } \\
\text { ment in Spanish } \\
\text { children: A longitu- } \\
\text { dinal analysis from } \\
\text { the MUGI project. }\end{array}$ & Spain & $\begin{array}{l}\text { A } \\
\text { longitudinal }\end{array}$ & $\begin{array}{l}\text { Primary } \\
\text { school } \\
\text { (8-11 years) } \\
\text { and } \\
\text { secondary } \\
\text { school } \\
\text { (12-16 years). }\end{array}$ & $\begin{array}{l}\text { During } \\
\text { confinement }\end{array}$ & $\begin{array}{l}\text { Before } \\
\text { confinement }\end{array}$ & Physical activity worsened. \\
\hline $\begin{array}{l}\text { López- } \\
\text { Bueno et al. } \\
\text { (2020) }\end{array}$ & $\begin{array}{l}\text { Health-Related } \\
\text { Behaviors Among } \\
\text { School-Aged Children } \\
\text { and Adolescents } \\
\text { During the Spanish } \\
\text { Covid-19 } \\
\text { Confinement. }\end{array}$ & Spain & $\begin{array}{l}\text { Cross- } \\
\text { sectional }\end{array}$ & $\begin{array}{l}\text { Children and } \\
\text { adolescents } \\
\text { aged between } \\
3 \text { and } 16 \\
\text { years }\end{array}$ & $\begin{array}{l}\text { During } \\
\text { confinement }\end{array}$ & $\begin{array}{l}\text { Before } \\
\text { confinement }\end{array}$ & $\begin{array}{l}\text { Significant differences were } \\
\text { found for a reduction of } \\
\text { weekly minutes of physical } \\
\text { activity during the confine- } \\
\text { ment. }\end{array}$ \\
\hline Francisco et & Psychological & Italy, & Cross- & Children and & During & Before & Before quarantine, most \\
\hline
\end{tabular}




\begin{tabular}{|c|c|c|c|c|c|c|c|}
\hline al. (2020) & $\begin{array}{l}\text { symptoms and } \\
\text { behavioral changes in } \\
\text { children and } \\
\text { adolescents during } \\
\text { the early phase of } \\
\text { COVID-19 quarantine } \\
\text { in three European } \\
\text { countries }\end{array}$ & $\begin{array}{l}\text { Spain, and } \\
\text { Portugal }\end{array}$ & sectional & $\begin{array}{l}\text { adolescents } \\
\text { between } 3 \\
\text { and } 18 \text { years } \\
\text { old }\end{array}$ & confinement & confinement & $\begin{array}{l}\text { children practiced } 30 \text { to } 60 \\
\text { min of physical activity } \\
\text { daily (33.1\%). However, in } \\
\text { quarantine, most children } \\
\text { experienced <30 min of } \\
\text { physical activity (53\%). }\end{array}$ \\
\hline $\begin{array}{l}\text { Bonavolontà } \\
\text { et al. (2020) }\end{array}$ & $\begin{array}{l}\text { Physical activities and } \\
\text { enjoyment during the } \\
\text { lockdown: Effect of } \\
\text { home-based super- } \\
\text { vised training among } \\
\text { children and } \\
\text { adolescents }\end{array}$ & Italy & $\begin{array}{l}\text { Cross- } \\
\text { sectional }\end{array}$ & $\begin{array}{l}\text { Children and } \\
\text { adolescents } \\
\text { (aged 6-11 } \\
\text { and aged 12- } \\
\text { 15) }\end{array}$ & $\begin{array}{l}\text { Received } \\
\text { online support } \\
\text { and guidance } \\
\text { from their } \\
\text { regular } \\
\text { instructors of } \\
\text { Tennis Schools } \\
\text { during } \\
\text { confinement }\end{array}$ & $\begin{array}{l}\text { Did not received } \\
\text { online support } \\
\text { and guidance } \\
\text { from their } \\
\text { regular instruc- } \\
\text { tors of Tennis } \\
\text { Schools during } \\
\text { confinement. }\end{array}$ & $\begin{array}{l}\text { Subjects appreciated the } \\
\text { home physical activities } \\
\text { with higher values from } \\
\text { those who received online } \\
\text { support and guidance from } \\
\text { their regular instructors of } \\
\text { Tennis Schools than who } \\
\text { did not }\end{array}$ \\
\hline
\end{tabular}

Table. 3 Characteristics Articles on the relationship between COVID-19 Lockdown and Sleep Habits in Children who are included in Qualitative Synthesis

\begin{tabular}{|c|c|c|c|c|c|c|c|}
\hline $\begin{array}{l}\text { Author } \\
\text { (Year) }\end{array}$ & Title & Country & $\begin{array}{l}\text { Study } \\
\text { Design }\end{array}$ & Population & Intervention & Comparison & Outcome \\
\hline $\begin{array}{l}\text { Francisco et } \\
\text { al. (2020) }\end{array}$ & $\begin{array}{l}\text { Psychological symp- } \\
\text { toms and behavioral } \\
\text { changes in children } \\
\text { and adolescents } \\
\text { during the early phase } \\
\text { of COVID-19 quaran- } \\
\text { tine in three European } \\
\text { countries }\end{array}$ & $\begin{array}{l}\text { Italy, } \\
\text { Spain, and } \\
\text { Portugal }\end{array}$ & $\begin{array}{l}\text { Cross- } \\
\text { sectional }\end{array}$ & $\begin{array}{l}\text { Children and } \\
\text { adolescents } \\
\text { between } 3 \\
\text { and } 18 \text { years } \\
\text { old }\end{array}$ & $\begin{array}{l}\text { During } \\
\text { confinement }\end{array}$ & $\begin{array}{l}\text { Before } \\
\text { confinement }\end{array}$ & $\begin{array}{l}\text { Increase in the amount of } \\
\text { sleep on weekdays. }\end{array}$ \\
\hline $\begin{array}{l}\text { Medrano et } \\
\text { al. (2020) }\end{array}$ & $\begin{array}{l}\text { Changes in lifestyle } \\
\text { behaviours during the } \\
\text { COVID-19 }\end{array}$ & Spain & $\begin{array}{l}\text { A } \\
\text { longitudinal } \\
\text { Study }\end{array}$ & $\begin{array}{l}\text { Children in } \\
\text { primary } \\
\text { school }\end{array}$ & $\begin{array}{l}\text { During } \\
\text { confinement }\end{array}$ & $\begin{array}{l}\text { Before } \\
\text { confinement }\end{array}$ & $\begin{array}{l}\text { Increased sleeping time } \\
\text { within both week and } \\
\text { weekend days. }\end{array}$ \\
\hline
\end{tabular}




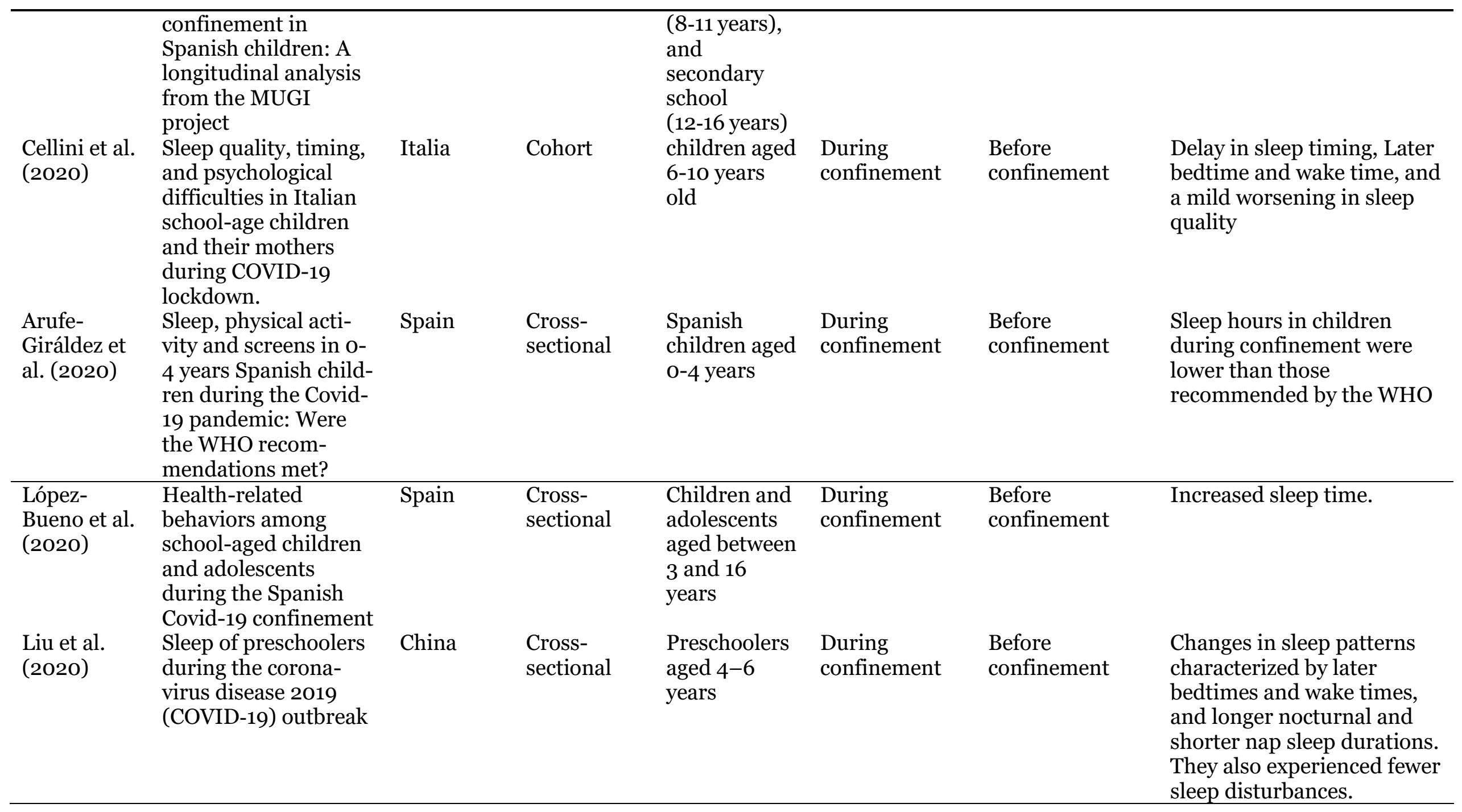




\section{CONFLICT OF INTEREST}

The author states that there is no conflict of interest in this study.

\section{FUNDING AND SPONSORSHIP}

This study uses the researchers' funds.

\section{ACKNOWLEDGEMENT}

Thanks to the online database providers PubMed and BASE.

\section{REFERENCE}

Aires L, Pratt M, Lobelo F, Santos RM, Santos MP, Mota J (2011). Associations of cardiorespiratory fitness in children and adolescents with physical activity, active commuting to school, and screen time. J Phys Act Health. 8(2): S198-S205. https://doi.org/10.1123/jpah.8.s2.s198

Andersen KL, Seliger V, Rutenfranz J, Nesset T (1980). Physical performance capacity of children in Norway. $\mathrm{V}$. The influence of social isolation on the rate of growth in body size and composition and on the achievement in lung function and maximal aerobic power of children in a rural community. Eur J Appl Phys Occup Physiol. 45(2-3): 155-166. https://doi.org/10.1007/BFo0421323.

Aparicio-Ugarriza R, Mielgo-Ayuso J, Ruiz E, Ávila JM, Aranceta-Bartrina J, Gil Á, Ortega RM, Serra-Majem L, Varela-Moreiras G, González-Gross M (2020). Active commuting, physical activity, and sedentary behaviors in children and adolescents from spain: findings from the anibes study. Int $\mathrm{J}$ Environ Res Public Health. 17(2): 668. https://doi.org/10.3390/ijerph17020668.

Arufe-Giráldez V, Sanmiguel-Rodríguez A, Zagalaz-Sánchez ML, Cachón-Zagalaz J, González-Valero G (2020). Sleep, physical activity and screens in $0-4$ years Spanish children during the COVID-19 pandemic: Were the WHO recommendations met?. J Hum Sport Exerc. 17(3). https://doi.org/10.14198/jhse.2022.173.02.

Baum KT, Desai A, Field J, Miller LE, Rausch J, Beebe D (2014). Sleep restriction worsens mood and emotion regulation in adolescents. J Child Psychol Psychiatry. 55(2):180-90. https://doi.org/10.1111/jcpp.12125.

Becker SP, Gregory A (2020). Perils and promise for child and adolescent sleep and associated psychopathology during the COVID-19 pandemic. J Child Psychol Psychiatry. 61(7): 757759. https://doi.org/10.1111/jcpp.13278.

Bonavolontà V, Cataldi S, Maci D, Fischetti F (2020). Physical activities and enjoyment during the lockdown: Effect of home-based supervised training among children and adolescents. J Hum Sport Exerc. 15(4): S1338-S1343. https://doi.org/10.14198/jhse.2020.15.Proc4.31.

Carskadon MA, Barker D (2020). Editorial Perspective: Adolescents' fragile sleepshining light on a time of risk to mental health. J Child Psychol Psychiatry. 61(10): 1058-1060. https://doi.org/10.1111/jcpp.13275.

Cellini N, Di Giorgio E, Mioni G, Di Riso D (2020). Sleep quality, timing, and psychological difficulties in Italian schoolage children and their mothers during COVID-19 lockdown:1-22. https://doi.org/10.31234/osf.io/95ujm

Francisco R, Pedro M, Delvecchio E, Espada JP, Morales A, Mazzeschi C,Orgilés M (2020). Psychological symptoms and behavioral changes in children and adolescents during the early phase of COVID-19 quarantine in 
three European countries. Frontiers in Psychiatry, 11, 570164. https://doi.org/10.3389/fpsyt.2020.570164

Gregory AM, O'Connor T (2002). Sleep problems in childhood: a longitudinal study of developmental change and association with behavioral problems. J Am Acad Child Adolesc Psychiatry. 41(8): 964-71. https://doi.org/10.1097/00004583-200208000-00015.

Guan H, Okely AD, Aguilar-Farias N, del Pozo Cruz B, Draper CE, El Hamdouchi A, Kontsevaya A (2020). Promoting healthy movement behaviours among children during the COVID-19 pandemic. Lancet Child Adolesc Health. 4(6): 416-418. https://doi.org/10.1016/s2352-4642(20)30131-o.

Jiao WY, Wang LN, Liu J, Fang SF, Jiao FY, Pettoello-Mantovani M, Somekh E (2020). Behavioral and emotional disorders in children during the COVID19 epidemic. J Pediatr. 221: 264-266.e1. https://doi.org/10.1016/j.jpeds.2020.03.013.

Liu Z, Tang H, Jin Q, Wang G, Yang Z, Chen H, Yan H, et al., (2021). Sleep of preschoolers during the coronavirus disease 2019 (COVID-19) outbreak. J Sleep Res. 30(1): e13142. https://doi.org/10.1111/jsr.13142.

López-Bueno R, López-Sánchez GF, Casajús JA, Calatayud J, Gil-Salmerón A, Grabovac I, Tully MA, Smith L (2020). Health-related behaviors among school-aged children and adolescents during the spanish covid-19 confinement. Front Pediatr. 8: 573. https://dx.doi.org/10.3389\%2Ffped.2020.005 73 .

Maugeri G, Castrogiovanni P, Battaglia G, Pippi R, D'Agata V, Palma A, Musumeci G (2020). The impact of physical activity on psychological health during Covid-19 pandemic in Italy. Heliyon,
6(6): 4315. https://doi.org/10.1016/j.heliyon.2020.e04315.

Medrano M, Cadenas-Sanchez C, Oses M, Arenaza L, Amasene M, Labayen I (2021). Changes in lifestyle behaviours during the COVID-19 confinement in Spanish children: A longitudinal analysis from the MUGI project. Pediatr Obes. 16(4): e12731. https://doi.org/https://doi.org/10.1111/ijpo.12731

Paavonen EJ, Porkka-Heiskanen T, Lahikainen A (2009). Sleep quality, duration and behavioral symptoms among 5-6 year old children. Eur Child Adolesc Psychiatry. 18(12): 747. https://doi.org/10.1007/s00787-009-0033-8.

Paruthi S, Brooks LJ, D’Ambrosio C, Hall WA, Kotagal S, Lloyd RM, Malow BA, et al., (2016). Consensus statement of the American Academy of sleep medicine on the recommended amount of sleep for healthy children: Methodology and discussion. J Clin Sleep Med. 12(11): 1549-1561. https://dx.doi.org/10.5664\%2Fjcsm.6288.

Pietrobelli A, Pecoraro L, Ferruzzi A, Heo M, Faith M, Zoller T, Heymsfield S (2020). Effects of COVID-19 lockdown on lifestyle behaviors in children with obesity living in Verona, Italy: a longitudinal study. (Silver Spring). 28(8): 1382-1385. https://doi.org/10.1002/oby. 22861.

Pombo A, Luz C, Rodrigues LP, Ferreira C, Cordovil R (2020). Correlates of children's physical activity during the COVID-19 confinement in Portugal. Public Health. 189: 14-19. https://doi.org/10.1016/j.puhe.2020.09.009.

Sprang G, Silman M (2013). Posttraumatic stress disorder in parents and youth after. Disaster Med Public Health. 7 (1): 105-110. https://doi.org/10.1017/dmp.2013.22.

Wang G, Zhang Y, Zhao J, Zhang J, Jiang F 
(2020). Mitigate the effects of home confinment on children during the COVID-19 outbreak. Lancet. 395 (10228): 945-947. https://doi.org/10.1016/So140-6736(20)30547-X

Widiyanto A, Asruria SF, Joko TA, Rina TH, Lidia EK (2020). The effect of social media exposure on depression and anxiety disorders in facing Covid19 pandemic. Eur J Mol Clin Med. 7 (5): 942-950. https://ejmcm.com/article_2956.html.
World Health Organization (2020). Coronavirus Disease 2019 (COVID-19). https://www.who.int/docs/defaultsource/coronaviruse/situationreports/20200226-sitrep-37-covid-19

Xiang M, Zhang Z, Kuwahara K (2020). Impact of COVID-19 pandemic on children and adolescents' lifestyle behavior larger than expected. Prog Cardiovasc Dis.30o(20): 96-97. https://doi.org/10. 1016/j.pcad.2020.04.013. 